\title{
HAZAIRIN DAN PENGHAPUSAN PIDANA PENJARA PENDEK
}

\author{
Ninik Zakiyah \\ Ikatan Remaja Masjid Baiturrahim Wedung Demak \\ e-mail: ninik.zakiyah@gmail.com
}

\begin{abstract}
This writing describes Hazarin thought of the ineffectiveness of short imprisonment in Indonesia and the study of possibility replacement of short prison sentences with social penalties. Hazarin said that short imprisonment is ineffective to give deterrent effect, and may even lead to negative stigmas and consequences such as the prisoners will become more virulent after being released from prison, that make people reject the presence of ex-prisoners. Hazarin offers the concept of criminal work in the public interest without being paid in lieu of imprisonment He also offers customary or Islamic law penalty to replace the short imprisonment as an alternative. Thus the replacement of the short sentence of imprisonment is in accordance with Islamic law and the first principle of Pancasila, the divinity of the God, the Almighty, who gives the human soul religious consciousness. Besides that, it is also in accordance with the fifth principle of Pancasila, the development of human awareness through moral education and justice for peace and justice social life. However, with the current conditions in Indonesia, the Hazainin thought doesn't seem applicable.
\end{abstract}

Tulisan ini menjelaskan pemikiran Hazairin tentang ketidak-efektifan pidana penjara pendek di Indonesia dan studi kemungkinan penggantian pidana pendek dengan hukuman yang bersifat sosial. Menurut Hazairin, pidana pendek tidak efektif memberi efek jera, bahkan dapat menimbulkan stigma dan akibat-akibat negatif seperti narapidana akan menjadi lebih jahat setelah keluar dari penjara, sehingga masyarakat akan menolak kehadiran mantan narapidana. Hazairin menawarkan konsep pidana bekerja untuk kepentingan umum tanpa dibayar sebagai penganti pidana penjara. Ia juga menawarkan mengganti pidana penjara pendek dengan pidana adat atau hukum Islam sebagai alternatif. Dengan demikian pengganti hukuman pidana penjara pendek tersebut sesuai dengan hukum Islam dan Pancasila, yakni sila pertama Ketuhanan Yang Maha Esa yang memberikan kesadaran agama dalam jiwa manusia. Disamping itu juga sesuai dengan sila kelima Pancasila, yang pengembangan kesadaran kemanusiaan melalui pendidikan moral dan keadilan sehingga menimbulkan keadilan dan ketentraman dalam kehidupan sosial. Namun dengan kondisi Indonesia saat ini, pemikiran Hazainin tersebut tampaknya belum dapat diaplikasikan.

Keywords: Hazairin; penghapusan; pidana; penjara pendek 


\section{Pendahuluan}

Hukuman pidana penjara ${ }^{1}$ hingga kini, masih menjadi pilihan utama untuk sarana politik kriminal. Hal ini tampak di berbagai peraturan perundangundangan yang ada dan diikuti dengan banyaknya penjatuhan pidana penjara. Namun demikian hingga kini masyarakat masih tidak puas dengan ketentuan hukuman tersebut. Hal ini terlihat dari adanya kritik bahwa penggunaan pidana penjara sebagai sarana penanggulangan kejahatan dipandang tidak efektif, disamping ada akibat negatif yang menyertainya.

Tujuan penjara ${ }^{2}$ diadakan untuk memberikan jaminan keamanan kepada rakyat banyak, agar terhindar dari gangguan kejahatan. Jadi pengadaan lembaga kepenjaraan itu merupakan respon dinamis dari rakyat untuk menjamin keselamatan diri. Dengan demikian penjara merupakan tempat menampung para terpidana agar masyarakat tidak terganggu, disamping sebagai upaya preventif (pencegahan), agar para penjahat tidak dapat merajalela. ${ }^{3}$

Kritik bahwa pidana penjara bukan sarana yang efektif untuk menanggulangi kejahatan antara lain pernah disampaikan The American Correctional Association pada tahun 1959, bahwa pidana penjara yang dilaksanakan berdasarkan pandangan yang bersifat pemidanaan semata-mata, akan lebih banyak menghasilkan penjahat daripada mencegahnya. Pidana penjara yang bersifat pemidanaan (punitive imprisonment) saat ini tidaklah merupakan alat pencegah yang efektif untuk kebanyakan penghuni penjara. ${ }^{4}$

Sorotan dan kritik-kritik tajam terhadap pidana penjara itu tidak hanya dikemukakan oleh para ahli secara perseorangan, tetapi juga oleh masyarakat bangsa-bangsa di dunia melalui beberapa kongres Internasional. Dalam satu

\footnotetext{
1Pidana penjara adalah bentuk pidana yang berupa kehilangan kemerdekaan. Lihat Andi Hamzah, Sistem Pidana dan Pemidanaan, cet1 (Jakarta: Pradnya Pramita, 1986), h. 27.

${ }^{2}$ Dewasa ini menggunakan istilah penjara untuk memberikan arti terhadap seluruh tempat tahanan bagi mereka, baik tersangka maupun penjahat yangmelakukan pelanggaran yang bertentangan dengan Undang-Undang. Kata "penjara" itu sendiri berasal dari kata "penjera", supaya orang itu jera tidak berbuat melanggar hukum lagi. Lihat A. Hamzah dan Siti Rahayu, Suatu Tinjauan Ringkas Sistem Pemidanaan Di Indonesia, cet.1 (Jakarta: Akademika Pressindo, 1983), h. 57 dan 29.

${ }^{3}$ Kartini Kartono, Patologi Sosial, Jilid 1, Edisi Baru (Jakarta: Rajawali, 1981), h. 186.

${ }^{4}$ Barda Nawawi Arief, Kebijakan Legislatif dalam Penanggulangan Kejahatan dengan Pidana Penjara (Semarang: Badan Penerbit UNDIP, 1996), h. 45.
} 
laporan Kongres PBB kelima tahun 1975 di Geneva mengenai Prevention on Crime and the Treatment of Offenders antara lain dikemukakan, bahwa di banyak negara terdapat krisis kepercayaan terhadap efektivitas pidana penjara, dan ada kecenderungan untuk mengabaikan kemampuan lembagalembaga kepenjaraan dalam menunjang usaha pengendalian kejahatan. Bahkan dalam perkembangan terakhir kritik-kritik tajam itu memuncak sampai ada gerakan untuk menghapuskan pidana penjara. Telah ada dua kali konferensi internasional mengenai penghapusan pidana penjara, yaitu International Conference on Penal Abolition (ICOPA). Pertama di Toronto, Kanada, pada bulan Mei 1983, dan kedua di Amsterdam, Nederland, bulan Juni $1985 .{ }^{5}$

Dalam disertasi Barda Nawawi Arief menyebutkan bahwa sebagian besar terpidana $(87,40 \%)$ dijatuhi pidana penjara di bawah satu tahun. ${ }^{6}$ Namun hingga saat ini dalam praktek justru pidana penjara paling banyak dipilih dalam penjatuhan pidana. Menurut Barda Nawawi Arief, bahwa dari sejumlah 434.313 terdakwa, yang diputus Pengadilan Negeri di seluruh Indonesia untuk perkara kejahatan dalam tahun 1973 sampai dengan tahun 1982 terdapat 355.456 terdakwa atau sekitar 81,84\% yang dijatuhi pidana penjara. ${ }^{7}$ Meskipun data tersebut sudah cukup lama, namun dapat menunjukkan bahwa pidana penjara paling banyak dipilih dalam praktek peradilan di Indonesia.

Pidana penjara akan menimbulkan sisi negatif, seperti hak kewarganegaraan yang hilang jika seseorang di dalam penjara, misalnya hak untuk bekerja, hak untuk memilih dan dipilih, hak untuk kawin, dan beberapa hak sipil lain. Begitu pula setelah lepas dari penjara, masih juga banyak masalah yang harus dihadapi oleh bekas narapidana, misalnya dalam mengurusi persyaratan administrasi tertentu dibutuhkan surat keterangan tidak pernah dipidana penjara, sekalipun pidana penjara berupa pidana penjara pendek. ${ }^{8}$

\footnotetext{
5Barda Nawawi Arief, Bunga Rampai Kebijakan Hukum Pidana (Perkembangan Penyusunan Konsep KUHP Baru, ed. 2, cet. 4 (Jakarta: Kencana, t.th.), h. 197-198.

${ }^{6}$ Ibid., h. 183. Berdasarkan hasil penelitian disertasi Barda, yang dijadikan buku dengan judul "Kebijakan Legislatif dalam Penanggulangan Kejahatan dengan Pidana Penjara", terbitan CV Ananta 1994; BP UNDIP 1996 dan 2000, dan Genta Publishing 2010.

${ }^{7}$ Barda Nawawi Arief, Kebijakan Legislatif, h. 43.

${ }^{8}$ Andi Hamzah, Sistem Pidana dan Pemidanaan Indonesia (dari Retribusi ke Reformasi), cet. 1 (Jakarta: Pradnya Paramita, 1986), h. 29.
} 
Ninik Zakiyah

Menurut Johannes Andenaes dalam tulisannya berjudul "Does Punishment Deter Crime"-sebagaimana dikutip oleh Barda Nawawi Arief- menyatakan bahwa: walaupun telah menjadi dogma di dalam penologi bahwa pidana penjara pendek merupakan pemecahan yang buruk karena tidak memberikan kesempatan untuk melakukan rehabilitasi, tapi sedikit bukti bahwa pidana penjara lama memberikan hasil lebih baik daripada pidana pendek ("there is little evidence that longer prison sentences give better result than short ones").9

Tiga belas setengah abad yang lampau, Nabi Muhammad berdasarkan atas kehendak Allah yang disampaikan kepadanya melalui ayat-ayat al-Qur'an, secara tegas menyatakan bahwa Islam mempertahankan "keseimbangan", misalnya dalam hal hukuman, setiap orang berhak memperoleh hukuman yang tidak berlebihan. ${ }^{10}$

Al-Qur'an tidak pernah mewajibkan umat Islam menyediakan penjara, malahan tidak pernah menganjurkan atau mengajarkannya, karena al-Qur'an tidak mengandung sebuah pelanggaran yang atasnya harus dikenakan hukuman penjara ataupun hukuman kurungan. Ini bukanlah disebabkan al-Qur'an tidak mengenal pengertian penjara, tetapi justru al-Qur'an telah mengenal penjara sebagaimana terdapat dalam QS. Yusuf: 33

Tidak adanya hukuman penjara bukan berarti bahwa tempat-tempat tahanan tidak diperlukan. Tempat-tempat tahanan mesti ada sebab dibutuhkan bagi kepentingan pemeriksaan, apalagi jika terdapat banyak orang yang harus diperiksa atau pemeriksaan itu memerlukan waktu yang panjang, tetapi sifat tempat tahanan tentu lain dari sifat penjara sebagai tempat hukuman.11

Hazairin mencoba untuk mengetahui arti Pancasila dan berusaha melengkapi tuntutan normatif Pasal 29 ayat 1 UUD 1945 yakni menjunjung tinggi agama, ${ }^{12}$ tetapi tidak memperdulikan hukum agama dan hukuman agama,

\footnotetext{
36.

9Barda Nawawi Arief, Kapita Selekta Hukum Pidana, cet 1 (Bandung: Citra Aditya Bakti, 2003), h.

${ }^{10}$ Baharuddin Lopa, al-Qur'an dan Hak-Hak Asasi Manusia (Yogyakarta: Dana Bhakti Prima Yasa, 1996), h. 53.

11 Ibid,, h. 29.

${ }^{12}$ Hazairin melihat bahwa Pasal 29 ayat 1 ini mempunyai fungsi besar dalam tata hukum di Indonesia ini karena dalam kehidupan bernegara Indonesia tidak boleh ada aturan hukum yang
} 
hukum agama tidak akan mencapai tujuannya tanpa ikut serta dijalankan hukuman-hukumannya. ${ }^{13}$

Hazairin dalam bukunya yang berjudul Tujuh Serangkai tentang Hukum juga menyebutkan bahwa pidana penjara merupakan suatu hukuman bagi mereka yang melanggar hukum pidana, mereka dicabut hak kebebasannya secara fisik dan dimasukkan ke dalam penjara dengan tujuan agar menjadi jera. Pada kenyataannya, penjara dijadikan sebagai sekolah kejahatan, menguras kas negara, bahkan terdapat perlakuan yang menyimpang di penjara seperti sodomi. Penjara menyiksa mental dan menjadikan seseorang penyakitan dan adakalanya si terhukum justru cenderung menjadi lebih jahat lagi dari sebelumnya. Dan bilamana semua pelaku tindak pidana dikenakan pidana penjara, maka rumah penjara akan menjadi penuh sesak. ${ }^{14}$ Hidup dalam penjara walaupun sekali dalam penjara yang super modern, adalah hidup yang sangat menekan jiwa, perasaan, pikiran dan hidup kepribadian. ${ }^{15}$

Tulisan ini mencoba mengungkap lebih jauh bagaimana pendapat Hazairin tentang penghapusan pidana penjara pendek dan bagaimana relevansinya dalam sistem pemidanaan hukum pidana Indonesia.

\section{Pemikiran Hazairin tentang Penghapusan Pidana Penjara Pendek}

Hazairin lahir pada 28 Nopember 1906 di Bukit tinggi, Sumatera Barat. Ayahnya bernama Zakaria Bahar, seorang guru, berasal dari Bengkulu. Ibunya berasal dari Minangkabau. Kakeknya bernama Ahmad Bahar, seorang muballigh terkenal pada zamannya. Itulah sebabnya sejak kecil Hazairin tumbuh dalam lingkungan yang penuh dengan bimbingan keagamaan, terutama dari kakeknya sendiri. Pendidikan agama inilah yang membentuk sikap keagamaannya yang demikian kuat dalam menempuh perjalanan karier dan

\footnotetext{
bertentangan dengan ajaran atau yang bertentangan dengan aturan ketuhanan Yang Maha Esa. Lihat Hazairin, Tujuh Serangkai tentang Hukum (Bandung: Bina Aksara, 1981), h. 5.

13Ibid, h. 5.

${ }^{14}$ Ibid, h. 34 .

15 Ibid, h. 3.
} 
hidupnya serta mewarnai pemikirannya, meskipun secara formal ia banyak menuntut ilmu di lembaga pendidikan Hindia Belanda. ${ }^{16}$

Di HIS (Hollands Inlandsche School) Bengkulu, Hazairin menempuh pendidikan formalnya yang pertama dan tamat pada tahun 1920. Kemudian ia ke Padang, melanjutkan pendidikannya di MULO (Meer Uitgebreid Lagere Onderwijs) dan tamat pada tahun 1924. Setelah dari Padang ia meneruskan lagi ke AMS (Algemene Middlebare School) yang bertempat di Bandung dan selesai pada tahun 1927, berikutnya pada tahun 1935 ia menempuh pendidikan kembali di RHS (Rechtkundige Hoogeschool/Sekolah Tinggi Hukum) jurusan hukum adat di Batavia (kini Jakarta) hingga mendapat gelar Mr. (Meester in de Rechten).

Setahun kemudian ia mendapatkan gelar doktor dengan judul disertasi De Redjang (membahas tentang adat istiadat Rejang di Bengkulu). ${ }^{17}$ Disamping belajar pendidikan umum, Hazairin belajar pendidikan agama dan bahasa Arab dari kakeknya. Untuk memahami lebih lanjut ajaran agama Islam ia belajar sendiri. Secara pasif ia menguasai bahasa Arab, Jerman dan Latin. Secara aktif ia menguasai bahasa Belanda, Inggris dan Perancis.

Nama lengkap Hazairin adalah Prof. Dr. Hazairin Alamsyah Harahap, S.H.18 Selain ahli hukum Islam, Hazairin juga ahli hukum adat yang pertama dari kalangan putera Indonesia. Ia adalah seorang ahli hukum adat dan hukum Islam terkemuka dari fakultas hukum Universitas Indonesia. Gelar kehormatan akademiknya adalah "Profesor". Pada tahun 1952 gelar tersebut ia terima dari Senat Guru Besar Universitas Indonesia atas prestasinya di kedua bidang hukum yakni hukum Islam dan Hukum Adat. ${ }^{19}$ Hazairin termasuk salah seorang nasionalis dan intelektual Muslim Indonesia yang berpendidikan Barat (Belanda).

${ }^{16}$ Tim Ensiklopedi, editor bahasa: Nina M. Armado, Ensiklopedi Islam (Jakarta: Ichtiar van Hoeve, 2005), h. 13.

${ }^{17}$ Ibid, h. 538.

18Ibid, h. 13.

${ }^{19}$ Tim Penulis IAIN Syarif Hidayatullah, Ensiklopedi Islam Indonesia, cet Ke-2 (Jakarta: Djambatan, 2002), h. 380. 
Atas jasa Hazairin yang peduli terhadap adat istiadat Tapanuli Selatan, ketika ia ditugaskan pemerintah Hindia Belanda di Pengadilan Negeri Padang Sidempuan dengan tugas tambahan sebagai peneliti hukum adat di sana, Hazairin mendapatkan gelar "Pangeran Alamsyah Harahap".20 Bukti atas kepeduliannya terhadap adat istiadat Tapanuli Selatan ini dituangkan dalam karya-karyanya dengan judul: De Redjang (disertasi doktornya, 1936), De Gevolgen van de Huwelijksontbiding in Zuid Tapanuli (Akibat Perceraian Perkawinan di Tapanuli Selatan, 1941), dan Reorganisatie van het Rechtswesen in Zuid Tapanulis (Reorganisasi Hukum di Tapanuli Selatan). ${ }^{21}$

Hazairin wafat pada 12 Desember 1975 di Jakarta, dikebumikan dengan upacara militer di Taman Makam Pahlawan Kalibata Jakarta. Atas jasanya, pemerintah Indonesia menganugerahinya Bintang Satya Lencana Widya Satia, Bintang Gerilya, Bhayangkara Kelas III, dan Bintang Kartika Eka Paksi Kelas III. Namanya diabadikan pada Universitas Hazairin (Unihaz) di Bengkulu. ${ }^{22}$

Pada tahun 1952, dalam kaitannya dengan hukum Adat dan hukum Islam Hazairin menulis artikel tentang pergolakan penyesuaian adat kepada hukum Islam. Pada tahun 1962, Hazairin berbicara tentang hukum perkawinan nasional. Hal ini dapat dilihat dalam karyanya tentang hukum kekeluargaan nasional yang berjudul "Hendak kemana Hukum Islam", dan ia juga menuliskan tentang perdebatan dalam seminar hukum nasional tentang farā'ị. ${ }^{23}$

Pemikirannya dalam pidana Islam serta keinginan diberlakukannya hukum pidana Islam di Indonesia dapat dilihat dalam karyanya dengan judul Demokrasi Pancasila yang ditulis pada tahun 1970.24

Bukunya Tujuh Serangkai tentang Hukum yang diterbitkan pada tahun 1973 merupakan kumpulan dari tujuh karyanya yaitu: Negara tanpa Penjara, Seklumit Persangkut-pautan Hukum Adat, Fungsi dan Tujuan Pembinaan Hukum dalam Negara RI yang Demokratis dan Berdasarkan Hukum, Muham-

\footnotetext{
${ }^{20}$ Tim Ensiklopedi, Ensiklopedi Islam h. 14.

${ }^{21}$ Tim Ensiklopedi, editor bahasa: Abdul Azis Dahlan, h. 538.

${ }^{22}$ Satjipto Rahardjo, Pembaharuan Hukum Islam di Indonesia, Hukum Adat dalam Studi Hukum dan Masyarakat (Jakarta: Universitas Indonesia, UI Press, 1976), h. 31.

${ }^{23}$ Tim Ensiklopedi, editor bahasa: Abdul Azis Dahlan, h. 539.

${ }^{24}$ Hazairin, Tujuh Serangkai tentang Hukum, h. 1.
} 
mad dan Hukum, Kesusilaan dan Hukum, Hukum Baru di Indonesia dan Ilmu Pengetahuan Islam dan Masyarakat. ${ }^{25}$

Dalam buku Tujuh Serangkai tentang Hukum, Hazairin mengemukakan, selagi kejahatan ada di muka bumi, selama setan belum terbelenggu, selama itulah penjara tentu diperlukan, dan sepertinya merupakan sebuah khayalan jika dunia ini berjalan tanpa kejahatan. Hazairin mencoba memikirkan bagaimana dunia mempunyai tertib hukum, namun terlepas dari wajib adanya penjara, bagaimana pula sebaik-baiknya menghadapi kejahatan dan membasminya. ${ }^{26}$

Hazairin memberikan contoh, misalnya dalam kitab Taurat yang berusaha membasmi perzinaan dengan rajam sampai mati, yaitu; beramai-ramai melempari orang yang bersalah dengan batu sampai mati, sedangkan al-Qur'an memberikan hukuman bagi perzinaan dengan hukuman dera (dicambuk) 100 kali dengan tidak boleh sampai mematikan, hukum Eropa modern menghukumnya dengan hukuman penjara, yaitu dalam hal-hal tertentu saja, tetapi menghalalkannya dalam keadaan-keadaan khusus lainnya. ${ }^{27}$

Hazairin dalam bukunya Tujuh Serangkai tentang Hukum juga mengemukakan, bagaimanapun bagusnya peraturan kepenjaraan, tidak akan ada orang yang berpikiran menyamakannya dan mensetarafkannya dengan suatu lembaga pendidikan akhlak. Tidak ada orang yang merasa berbahagia, merasa lega dan merasa mendapat ketenteraman dan ketenangan jiwa dengan berdiam beberapa lama di dalam penjara. Dengan demikian Hazairin mengemukakan bahwa lamanya pidana penjara hanya menyengsarakan dan merugikan banyak hal, serta lembaga penjara tidak bisa disetarakan dengan lembaga pendidikan, apalagi penjara pendek dirasa kurang dalam memberikan penjeraan serta hal-hal yang mendidik, jika penjara lama saja masih kurang dan banyak kerugiannya.

25Ibid., h. 3.

26Ibid, h. 2.

${ }^{27} \mathrm{Ibid}$, di dalam hukum adat pada masyarakat yang menghalalkan zina dalam bentuk-bentuk tertentu (Minahasa, Bali, Mentawai) dan ada pula yang menghukumnya dengan hukum berat, misalnya hukum mati dan sebagainya. Setiap masyarakat menentukan bentuk-bentuk hukumannya menurut pilihanya dan pilihan itu adalah hasil dari pandangan hidup filsafatnya, kepercayaanya dan agamanya. 
Kemudian Hazairin menganalisis bahwa, penghapusan sangat menguntungkan di bidang materiil. Selama ini masyarakat banyak menanggung biaya untuk pembangunan penjara, untuk personelnya, pemeliharaan, perlengkapan, makan serta minum, pengobatan penghuni-penghuninya, dan sebagainya. Mengurangi jumlah penjara dapat memberikan banyak keuntungan meteriil yang dapat disalurkan dan dimanfaatkan bagi kepentingan pembangunan dan perbaikan masyarakat, apalagi untuk negara yang sedang berkembang dan membangun seperti negara kita sekarang ini. Dalam rangka akselerasi pembangunan dalam tempo 25 tahun yang menjadi cita-cita negara sekarang ini maka gagasan penghapusan penjara ini patut direnungkan dan dilaksanakan sekuat tenaga dan kemampuan. ${ }^{28}$

Pada sisi lain Hazairin berpendapat tentang perlu adanya penjara, namun dengan sifat yang lain. Hazairin mengutarakan bahwa tidak adanya hukuman penjara bukan berarti bahwa tempat-tempat tahanan tidak diperlukan. Tempat-tempat tahanan musti ada sebab dibutuhkan untuk kepentingan pemeriksaan, apalagi jika terdapat banyak orang yang musti diperiksa, ataupun pemeriksaan itu memerlukan waktu lama, tapi sifatnya tentu lain dari sifat penjara sebagai tempat menjalankan hukuman..$^{29}$

Dalam bukunya Tujuh Serangkai tentang Hukum, Hazairin mengemukakan salah satu pidana alternatif bagi pidana penjara dengan waktu singkat (pendek) adalah pidana bekerja untuk kepentingan umum tanpa dibayar. Sistem ini telah dikenal dalam sejarah hukum pidana Eropa sejak beberapa puluh tahun lampau. Pada umumnya, hukuman ini juga dikenal sebagai pengganti pidana denda, seperti yang diterapkan di Portugis, Inggris, dan Jerman..$^{30}$

Hazairin juga membandingkan hukuman alternatif di berbagai negaranegara lain seperti Belanda dan Luxemburg, terlebih dahulu memperoleh pidana penjara atau pidana denda melalui grasi (ampunan dari kepala negara

\footnotetext{
${ }^{28}$ Penjara sudah dapat diatur makin lama makin berkurang sedangkan praktek hidup menampakkan tanda-tanda yang nyata bahwa mereka itu bukanlah berkurang malah bertambah saja. Lihat Hazairin, Tujuh Serangkai tentang Hukum., h. 4.

${ }^{29} \mathrm{Ibid}$, h. 29.

${ }^{30}$ Hazairin, Tujuh Serangkai tentang Hukum , h. 5.
} 
kepada orang yang mendapat hukuman), untuk kemudian sisa waktu dari penghukuman tersebut diubah menjadi pidana bekerja tanpa dibayar. ${ }^{31}$

Menurut Hazairin alasan setelah ia membandingkan berbagai hukuman sebagai pengganti pidana alternatif dari pidana penjara di Indonesia khususnya, adalah perlunya alternatif pengganti pidana penjara terhadap pelaku tindak pidana, yaitu hukum pidana Islam dan pidana kerja sosial (socially useful works/community service order). Hal ini didasarkan pemikiran bahwa dalam perspektif penologi ${ }^{32}$, jenis pidana yang dijatuhkan terhadap pelaku kejahatan harus dapat mencapai tujuan pemidanaan, baik dalam konteks prevensi umum maupun prevensi khusus, namun pelaksanaan pidana dan tindakan ternyata sistem perawatan yang berperikemanusiaan (misalnya pidana percobaan/probation) sedikit lebih efektif untuk mengurangi kemungkinan pengulangan tindak pidana (residivisme) dibandingkan dengan beberapa bentuk pidana lainnya.

Dalam hukum pidana Islam, Hazairin memberikan pemikirannya tentang bentuk pidana yang dijatuhkan dalam hukum adat seperti hukuman mati, pengasingan, pemukulan atau ganti rugi. Pelaksanaan hukuman mati dalam hukum adat berbeda-beda di setiap daerah, ada yang dilempar dengan batu, dipenggal, dibuang ke laut, ditumbuk, dilesung, ditikam dengan keris dan metode lain yang disesuaikan dengan karakter masing-masing daerah. ${ }^{33}$

Penjatuhan pidana kerja sosial didasarkan pada konsepsi individualisasi pemidanaan sebagaimana dirancang dalam RUU KUHP Indonesia Tahun 2005. Pidana kerja sosial dapat diterapkan di Indonesia karena secara filosofis, teoretis, yuridis dan empiris selaras dengan pemikiran dalam RUU KUHP. 34

Hazairin mengartikan pidana kerja sosial selaras dengan sila ke lima Pancasila, yaitu Keadilan Sosial bagi Seluruh Rakyat Indonesia, yang di dalamnya terkandung nilai bekerja keras. Dalam menjalankan pidana kerja

\footnotetext{
${ }^{31}$ Barda Nawawi Arief, Kapita Selekta Hukum Pidana, h. 30.

32Penologi yaitu ilmu yang mempelajari hukuman serta pencegahan dengan cara yang tidak bersifat hukuman, dan banyak manfaatnya terhadap narapidana.

${ }^{33}$ Hazairin, Tujuh Serangkai tentang Hukum., h. 28.

${ }^{34}$ Rancangan Undang-Undang tentang Kitab Undang-Undang Hukum Pidana (KUHP) Tahun 2005.
} 
sosial, terpidana dituntut bekerja keras dalam menjalani pemidanaan. ${ }^{35}$ Sedangkan secara teoritis pidana kerja sosial sesuai dengan ajaran teori gabungan. Menurut teori gabungan (vernengings theorien), dalam penjatuhan pidana perlu adanya pemilahan dan pembedaan antara tahap-tahap pemidanaan narapidana, dan berat ringannya tindak pidana karena teori ini menggabungkan antara unsur pembalasan dengan unsur tujuan (prevensi). ${ }^{36}$

Secara empiris, keunggulan pidana kerja sosial dibandingkan dengan jenis pidana lain adalah: dapat mencegah stigmatisasi dan prisonisasi terpidana, narapidana dapat memperbaiki tingkah laku dengan fasilitas yang ada di masyarakat, melindungi terpidana dan masyarakat. ${ }^{37}$

Dalam pidana kerja sosial terkandung unsur rehabilitasi, redukasi, dan resosialisasi. Selama menjalankan pidana, narapidana dibina dan dibimbing dari sisi pembentukan sikap dan tingkah laku oleh petugas kemasyarakatan dari Balai Pemasyarakatan (BAPAS), wali narapidana (dari BAPAS), pamong narapidana (dari pegawai tempat pelaksanaan pidana), dari lembaga khusus yang dibentuk pemerintah (misalnya dari sukarelawan). Selama menjalankan pidana, perkembangan pekerjaan dan kepribadian terpidana selalu diawasi dan dipantau oleh petugas kemasyarakatan. Hasil pengawasan dan pengamatan tersebut dapat digunakan sebagai sarana membimbing narapidana agar dapat berperilaku baik serta aktif berpartisipasi dalam pembangunan. ${ }^{38}$

Dengan persoalan di atas setidaknya Indonesia menerapkan pidana kerja sosial sebagai ganti pidana penjara pendek, dengan ini narapidana dapat terhindar dari stigmatisasi dan prisonisasi, disamping itu narapidana dalam pidana penjara pendek tidak mengikuti pembinaan secara maksimal di lembaga pemasyarakatan dikarenakan singkatnya waktu pemenjaraan. Pidana kerja sosial ini juga tepat jika dijatuhkan kepada penjahat yang pertama kali melakukan kejahatan. ${ }^{39}$

\footnotetext{
${ }^{35}$ Hazairin, Tujuh Serangkai tentang Hukum, h. 32.

36Ibid, h. 57.

${ }^{37} \mathrm{Ibid}$, h. 47.

38Tongat, Pidana Kerja Sosial dalam Pembaharuan Hukum Pidana Indonesia (Jakarta: Djambatan, 2001), h. 47.

${ }^{39} \mathrm{Ibid}$, h. 47.
} 
Ninik Zakiyah

\section{Analisis terhadap Pemikiran Hazairin tentang Penghapusan Pidana Penjara Pendek}

Dinamika perjalanan hidup seorang tokoh tidak dapat dilepas begitu saja apabila hendak memahami pandangannya. Hal ini terjadi karena pikiran manusia tidak muncul dari ruang hampa. Ia pasti terkait dengan situasi dan kondisi tertentu yang melingkupinya. Bahkan terdapat suatu pemikiran yang tidak akan dapat dipahami sama sekali, kecuali jika penulis menggunakan konteks kemasukakalan (plausibility context) di mana pemikiran itu muncul.40

Dengan teori relasionalnya, Karl Mannheim ${ }^{41}$ menekankan pentingnya penulis mengetahui hubungan antara pemikiran dengan konteks sosialnya. Teori itu mengatakan bahwa setiap pemikiran selalu berkaitan dengan keseluruhan struktur sosial yang melingkupinya. ${ }^{42}$

Dengan demikian, kebenaran pemikiran sesungguhnya hanyalah kebenaran kontekstual, bukan kebenaran universal. Untuk itu, memahami butirbutir pemikiran seseorang haruslah tetap berpijak pada konteks dan struktur kemasukakalan yang dimiliki oleh orang tersebut. Hal demikian itu sudah barang tentu juga berlaku bila penulis ingin memahami sosok pemikiran Hazairin.

Hazairin menolak model teleologis Hegelian, di mana satu mode produksi mengalir secara dialektis dari model produksi yang lain, dan memilih taktik kritik Nietzschean melalui pengajuan pembedaan (difference). Sejarawan Nietzschean memulai dari masa kini dan bergerak mundur ke masa lalu sampai perbedaan itu ditemukan. Ia akan bergerak maju kembali, menelusuri proses transformasi dan berusaha mempertahankan, baik diskontinuitas

\footnotetext{
40Muhyar Fanani, Membumikan Hukum Langit, Nasionalisasi Hukum Islam dan Islamisasi Hukum Nasional Pasca Reformasi (Yogyakarta: Tiara Wacana, 2008), h. 171.

${ }^{41}$ Karl Mannheim (1893-1947) adalah sosiolog Jerman yang dipengaruhi pemikiran Marx, tetapi menganjurkan perbaikan masyarakat melalui usaha-usaha pembaruan secara bertahap dan bukannya dengan revolusi. Salah satu magnumopusnya adalah Ideology and Utopia (Ideologi dan Utopia) tahun 1929. Lihat Ali Mudofir, Kamus Filsuf Barat (Yogyakarta: Pustaka Pelajar, 2001), h. 339

${ }^{42}$ Karl Mannheim, Ideology and Utopia, an Introduction to the Sociology of Knowledge, Terj. F. Budi Hardiman, Ideologi dan Utopia; Menyingkap Kaitan Pikiran dan Politik (Yogyakarta: Kanisius, 1991), h. 306.
} 
(ketidak sinambungan) maupun kontinuitas (berkesinambungan atau saling berkaitan dengan sebelumnya). Inilah model yang digunakan Hazairin.43

Dalam beberapa hal, analisis genealogis berbeda dengan bentuk-bentuk analisis sejarah tradisional. Sementara analisis sejarah tradisional atau total memasukkan peristiwa-peristiwa ke dalam sistem penjabaran besar (grand explanatory) dan proses linier, merayakan peristiwa dan tokoh besar serta berusaha mendokumentasikan asal-usul kejadian, sedangkan analisis genealogis berusaha membangun dan mempertahankan singularitas peristiwa, meninggalkan peristiwa spektakuler untuk peristiwa sepele dan yang diabaikan, serta keseluruhan tentang fenomena yang sering ditolak sebagai sejarah. Di sinilah letak kekuatan Hazairin, kelebihannya adalah analisis yang bersifat khusus seperti analisis hukum adat, hukum kewarisan bilateral. ${ }^{44}$

Hazairin dalam bukunya yang berjudul Tujuh Serangkai tentang Hukum memusatkan perhatian di khalayak ramai, pemikiran tersebut menjadi perdebatan yang krusial di kalangan hukum. Dalam karangannya ia mendapatkan pemikiran baru tentang penjara, ia menyatakan bahwa penjara tidaklah banyak memberi manfaat dalam penegakan hukum di negeri ini. ${ }^{45}$

Menurut Hazairin, penjara hanya berfungsi sebagai tempat pengekang kemerdekaan pelaku tindak pidana, dan hanya bermanfaat sesaat saja. Penjara menjadi tempat bagi para penjahat untuk bersantai sejenak setelah melakukan tindak pidana, serta sebagai tempat menikmati kepuasaannya setelah melakukan kejahatan ataupun untuk menghindari amukan dari orang yang membencinya.

Hazairin juga mempelajari tentang pengaturan mengenai pidana penjara sebagai salah satu pidana pokok yang terdapat dalam Pasal $10 \mathrm{KUHP}$. Belanda telah memperkenalkan sistem pidana penjara ke Indonesia ketika mereka menjajah Indonesia, kemudian menerapkan Wetboek van Strafrecht (WvS)

\footnotetext{
43Madam Sarup, An Introductory Guide to Post-Structuralism and Postmodernism, Terj. Medhy Aginta Hidayat, Poststrukturalisme dan Postmodernisme, Sebuah Pengantar Kritis (Yogyakarta: Jendela, 2003), h. 100.

${ }^{44}$ Ibid, h. 137.

${ }^{45}$ Hazairin, Tujuh Serangkai tentang Hukum, h. 2.
} 
mereka di negeri ini. WvS inilah yang kemudian menggusur peranan hukum adat dan hukum agama yang selama ini telah mengatur ketertiban hidup masyarakat Indonesia. ${ }^{46}$

Hazairin memberikan pemikirannya tentang bentuk pidana yang dijatuhkan dalam hukum adat seperti hukuman mati, pengasingan, pemukulan atau ganti rugi. Pelaksanaan hukuman mati dalam hukum adat berbeda-beda di setiap daerah, ada yang dilempar dengan batu, dipenggal, dibuang ke laut, ditumbuk, dilesung, ditikam dengan keris, dan metode lain yang disesuaikan dengan karakter masing-masing daerah.

Di negara-negara Islam seperti Arab Saudi, Libya, Pakistan, Iran dan negara yang mayoritas penduduknya Muslim, mereka masih menggunakan hukum pidana Islam sebagai hukuman bagi orang yang melanggar aturan dalam pemerintah yang mengakibatkan keresahan bagi warga Muslim. Di Indonesia adalah mayoritas Muslim, tetapi hanya sebagian daerah yang menjalankan hukum pidana Islam seperti di Propinsi Aceh, tuntutan atas pemberlakuan hukum pidana Islam semakin keras terdengar. Hal ini semakin menguat disetujuinya RUU Nanggroe Aceh Darussalam, serta lahirnya beberapa peraturan daerah yang sesuai dengan ajaran Islam. ${ }^{47}$

Sebagai tokoh ahli hukum adat dan hukum Islam, Hazairin juga memberikan pemikiran solutifnya atas penghapusan ini, ia menganjurkan penerapan hukum Islam sebagai penggantinya. Hukum Islam yang dimaksud Hazairin adalah hukuman ta'zir, hukuman yang bersifat mendidik. Ia berharap agar hukum Islam diberlakukan di Indonesia. Selain itu, ia juga berpendapat diterapkannya pula sistem peradilan Islam, kemudian hakimnya adalah hakim pidana Islam yang mengetahui pengadilan setiap kali ada perkara pidana Islam yang akan diadili.

Sementara itu dalam hukum Islam, para pelaku jarimah akan dijatuhkan hukuman seperti hukuman mati, dera, diyat, qishāsh, pembuangan, kaffärah dan ta'zïr. Sistem penjara di Indonesia ditemukan di dalam KUHP, dimana KUHP

\footnotetext{
${ }^{46}$ Hasbullah Bakry, Pembaharuan Hukum Islam di Indonesia, Segi-segi yang Menarik dari Kepribadian Prof. DR. Hazairin (Jakarta: Universitas Indonesia Press, 1976), h. 27.

${ }^{47}$ Makhrus Munajat, Hukum Pidana Islam di Indonesia (Yogyakarta: Bidang Akademik Uin Sunan Kalijogo, 2008), h. 384.
} 
merupakan aturan hukum yang berasal dari Negara Belanda. Berbeda dengan hukum adat dan hukum Islam yang telah menjadi jiwa bangsa Indonesia, karena sistem hukum itu telah ada sejak lama di negeri ini.

Hukuman penjara dalam hukum pidana Islam dibagi menjadi dua, yaitu hukuman penjara terbatas dan tidak terbatas (seumur hidup). Hukuman penjara tidak terbatas tidak dibatasi waktunya, melainkan berlangsung terus menerus sampai orang yang terhukum mati, atau sampai ia bertobat. Dalam istilah lain bisa disebut hukuman penjara seumur hidup.

Hukuman penjara terbatas adalah hukuman penjara yang lama waktunya dibatasi secara tegas. Adapun lamanya hukuman penjara tidak ada kesepakatan di kalangan para ulama. Sebagian ulama berpendapat bahwa lamanya penjara bisa dua bulan atau tiga bulan atau kurang lebih. Sebagian lagi berpendapat bahwa penentuan tersebut diserahkan kepada hakim.48

Hazairin berharap dengan adanya penjara dapat pula menjadi tempat pembinaan, sehingga setelah selesai menjalani pidana, terpidana menjadi orang yang lebih baik dari sebelumnya. Tujuan dan alasan pembenaran dalam pidana penjara adalah untuk melindungi masyarakat. Tujuan ini hanya bisa dicapai bila masa hilangnya kemerdekaan itu diarahkan sebanyak mungkin agar terpidana dapat kembali ke masyarakat atau resosialisasi.

Namun untuk pelaksanaan pembinaan tersebut diperlukan waktu yang cukup untuk program dan metode pembinaan, yang pada akhirnya akan mempengaruhi hasil akhir dari pemidanaan. Kemudian terhadap pidana penjara dengan waktu singkat banyak kelemahan, dan kelemahan utamanya adalah bahwa kesempatan untuk melakukan pembinaan waktunya kurang karena pendeknya waktu di penjara, sehingga tujuan membuat terpidana jera masih sangat kurang.

Selain itu anggapan Hazairin terkait pendeknya waktu dengan pidana penjara hanya memberikan kesempatan kepada terpidana untuk menggunakan umur mereka selama dalam lembaga untuk berguru kepada penjahat profesional. Sehingga terpidana akan semakin jahat.

\footnotetext{
${ }^{48}$ Ahmad Wardi Muslich, Hukum Pidana Islam, cet. 2 (Jakarta: Sinar Grafika, 2005), h. 262-263.
} 
Menurut Hazairin, semua kelemahan pada pidana penjara dimiliki oleh pidana penjara sementara waktu, tapi terdapat satu keuntungan yang ada pada pidana penjara dimiliki oleh pidana penjara sementara waktu. Salah satu keuntungan dari pidana sementara waktu adalah jangka waktunya yang pendek sehingga penderitaan terpidana dan keluarganya tidak terlampau berat.

Namun demikian tidak berarti bahwa pidana penjara seumur hidup atau jangka panjang tidak memiliki kelemahan karena dengan pidana ini terpidana akan makin terasing dengan masyarakat yang akibat selanjutnya akan kehilangan kemampuan melanjutkan kehidupan secara produktif dalam masyarakat. Namun jika dilihat dari sudut filsafat pembinaan, pidana penjara jangka panjang lebih memberikan harapan. Namun juga memiliki kekurangan, misalnya menguras kas negara. Biaya untuk operasional dan administrasi penjara cukuplah besar, dan itu diambil dari uang negara.

Selain di atas masih banyak kekurangan yang lain misalnya, perlakuan yang menyimpang seperti sodomi, melakukan hubungan seks sesama sejenis (homoseksual) dan mendapatkan pembinaan yang kurang maksimal di dalam penjara.

Penjara pada zaman Belanda pada umumnya digunakan untuk menahan para pejuang kemerdekaan. Di dalam penjara mereka menyiksa dan berusaha menjatuhkan mental setiap pejuang atau untuk menyuci otak mereka. Maka sekarang ini sungguh tidak lagi efektif. ${ }^{49}$

Hazairin menginginkan agar penjara lebih baik dijadikan saja sebagai tempat tinggal bagi beribu tunawisma yang bertebaran di negeri ini, yang hidup di emperan toko atau kolong jembatan. Anggaran negara yang awalnya setiap tahun di alokasikan untuk penjara bisa di alihkan untuk rakyat miskin. ${ }^{50}$

Di sinilah Hazairin sangat setuju dengan aspek historis hukum Islam yang menunjukkan dengan jelas bahwa perkembangan aspek substantif hukum ini sejak fase awal pertumbuhannya tidak resisten terhadap pengaruh asing. Sejak masa awal pertumbuhannya, hukum Islam senantiasa menyambut positif

\footnotetext{
${ }^{49}$ Dwidja priyanto, Sistem Pelaksanaan Pidana Penjara di Indonesia (Bandung: Rafika Aditama, 2006), h. 84.

${ }^{50}$ Hazairin, Tujuh Serangkai tentang Hukum, h. 13.
} 
terhadap nilai-nilai dari luar yang dipandang masih masuk dalam batas ajaran Islam. 51

\section{Relevansi Penghapusan Pidana Penjara Pendek terhadap Sistem Pemidanaan Hukum Pidana di Indonesia}

Paradigma baru Hazairin tentang penjara pendek ini dapat dimasukkan dalam kategori pemikiran utopis, karena ia masih menggunakan asumsiasumsi lama dalam membangun ide-idenya. Karena menggunakan paradigma lama dalam membaca sejarah serta relasi kuasa dan pengetahuan, maka pemikiran Hazairin dapatlah disebut sebagai pemikiran utopia relatif. Hal ini menjadi penting, karena penelusuran semacam ini akan menentukan apakah tawaran dari Hazairin ini dapat diterima dan pada akhirnya dapat dijadikan pegangan atau akan hilang begitu saja.

Dalam kongres PBB yang diselenggarakan 5 tahun sekali mengenai "The Prevention of Crime and Treatmen of Offenders" bahwa hukum pidana yang selama ini ada di beberapa negara (terutama yang berasal dari hukum asing semasa zaman kolonial) pada umumnya bersifat "absolete and unjust" (telah usang dan tidak adil) serta "outmoded and unreal" (sudah ketinggalan zaman dan tidak sesuai dengan kenyataan). Hal ini disebabkan karena sistem hukum pidana di beberapa negara yang berasal dari impor dan semasa zaman kolonial, tidak berakar pada nilai-nilai budaya dan bahkan "diskrepansi" dengan aspirasi masyarakat, serta tidak responsif terhadap kebutuhan sosial masa kini. Faktor demikian oleh konggres PBB dinyatakan sebagai faktor kontribusi terjadinya kejahatan (a contributing factor to the increas of crime). Bahkan dinyatakan pula pembangunan (termasuk di bidang hukum) yang mengabaikan nilai-nilai moral dan kultural, antara lain dengan masih berlakunya hukum warisan zaman kolonial yang menjadi faktor kriminogen. 52

Hazairin ingin mengahapuskan pidana penjara pendek karena tidak efektifnya pidana penjara dalam hukum pidana di Indonesia, untuk itu

\footnotetext{
51S.M. Amin, Pembaharuan Hukum Islam di Indonesia, Mengenang Prof. DR. Hazairin (Jakarta: VI Press, Unversitas Indonesia, 1976), h. 49.

${ }^{52}$ Barda Nawawi Arief, Pembaharuan Hukum Pidana dalam Perspektif Kajian Perbandingan (Bandung: Citra Aditya Bakti, 2005), h. 8.
} 
Hazairin ingin kembali kepada hukuman yang ada dalam hukum adat, dan hukum pidana Islam sebagai alternatif dari pidana penjara. Hazairin juga memberikan pendapatnya tentang pengganti alternatif pidana penjara pendek dengan sanksi sosial. 53

Sehingga Hazairin mencoba untuk mengetahui arti sebuah Pancasila, berusaha melengkapi tuntutan normatif Pasal 29 ayat 1 UUD 1945 yakni menjunjung tinggi agama, ${ }^{54}$ dengan ikut serta menjalankan hukuman-hukuman agama agar tercapai tujuannya. Hal ini juga berlaku dalam bidang hukum yang bukan hukum agama. Menurut Hazairin hukum Islam menggunakan prinsip memelihara masyarakat secara mutlak dan mewajibkan untuk dipenuhi dalam setiap hukuman yang ditetapkan untuk setiap tindak pidana. Karena itu setiap hukuman haruslah dengan kadar yang cukup untuk dapat mendidik si pelaku serta dapat mencegah agar tidak kembali mengulangi tindak pidananya. Hukuman itu juga harus cukup untuk dapat mencegah orang lain melakukan tindak pidana.

Menurut hemat penulis secara rasional memang pemikiran Hazairin pantas dijadikan sebagai pedoman dalam pemidanaan, namun kalau dikaitkan dengan perkembangan kejahatan yang ada di Indonesia sekarang ini, pemikiran tersebut tidak menjadikan masyarakat Indonesia lebih aman dan tenteram melainkan membuat masyarakat menjadi resah karena sistem yang ada dalam pandangan Hazairin itu sangat tradisional.

Di Indonesia, penjara merupakan salah satu bentuk hukuman yang paling dominan. Artinya, dari sekian banyak bentuk hukuman yang diberikan dalam Undang-Undang Pidana, hukuman penjara masih menjadi prioritas. Meskipun tidak menafikan bentuk-bentuk hukuman yang lain.

Sejak kelahirannya, penjara bukan semata-mata merupakan perangkat perampas kebebasan, melainkan sebagai perangkat penghukuman yang

${ }^{53}$ Hazairin, Tujuh Serangkai tentang Hukum, h. 32.

${ }^{54}$ Hazairin melihat bahwa Pasal 29 ayat 1 ini mempunyai fungsi besar dalam tata hukum di Indonesia ini karena dalam kehidupan bernegara Indonesia tidak boleh ada aturan hukum yang bertentangan dengan ajaran atau yang bertentangan dengan aturan Ketuhanan Yang Maha Esa. 
memiliki fungsi korektif, sekalipun waktunya pendek. Penjara menandai momen penting sejarah peradilan, yakni pendekatan kemanusiaan. Penjara juga menandai perkembangan mekanisme disiplin. .5

Meskipun pelaksanaan hukuman pemenjaraan tetap menunjukkan adanya dominasi dari tipe kuasa tertentu, tetapi pemenjaraan tetap dianggap sebagai bentuk penghukuman dari masyarakat yang berbudaya. Penjara memperbaiki individu tanpa melukai dan menghilangkan anggota tubuh. Pemenjaraan mendasarkan mekanismenya pada bentuk sederhana perampasan kebebasan. Penjara mengambil waktu dari individu, mengukur bobot hukuman secara tepat melalui variasi lamanya waktu penahanan. Dengan mengambil waktu dari narapidana, penjara menampilkan ide bahwa kejahatan telah dibalas. Penjara menggunakan waktu sebagai ukuran penghukuman karena waktu merupakan hal yang dimiliki oleh individu. ${ }^{56}$

Sebagaimana pendapat Hazairin, menurut hemat penulis penjara juga mendasarkan perannya sebagai perangkat untuk mengubah individu-individu. Penjara secara kualitatif tidak berbeda dengan barak militer, sekolah atau bengkel kerja yang dimaksudkan untuk mengoreksi dan melatih kembali individu-individu. Dengan memasukkan narapidana ke dalam mekanismenya, penjara melatih kembali narapidana, membuatnya patuh dan membuat mereka menjadi individu yang berguna. Dua pondasi utama pemenjaraan yakni pembayaran utang melalui perampasan waktu dan penggunaan teknik disiplin untuk mengoreksi individu membentuk penjara menjadi bentuk hukuman yang paling tepat dan memasyarakat.

Berdasarkan uraian tentang pendapat pro dan kontra terhadap penerapan pidana penjara pendek, menurut penulis pidana penjara pendek masih diperlukan dalam sistem pemidanaan dan layak diancamkan terhadap pelaku kejahatan di Indonesia, tetapi penjatuhannya perlu dibatasi berdasarkan prinsip-prinsip dan persyaratan tertentu serta ditunjang oleh konsepsi individualisasi pemidanaan.

\footnotetext{
55Barda Nawawi Arief, Pembaharuan Hukum Pidana, h. 103.

${ }^{56}$ Sudarto, Kapita Selekta Hukum Pidana (Bandung: Alumni, 1981), h. 5.
} 
Jika penulis mencermati sistem pemasyarakatan yang ada di Indonesia, setidaknya ada tiga macam keuntungan yang bisa diambil darinya. Pertama, dari segi ekonomi, membuat pelaksanaan kekuasaan atau pendisiplinan lebih murah. Kedua, dari segi politik, merupakan bentuk kontrol yang tidak kelihatan dan mencegah perlawanan, dampak kekuasaan sosial ini menjangkau secara intensif dan luas dengan resiko kegagalan rendah. Ketiga, memaksimalkan manfaat sarana pedagogi dengan tekanan memaksimalkan peran unsurunsur dalam sistem.

Menurut hemat penulis pidana penjara sedikit banyak membantu mengatasi problem-problem pembinaan narapidana yang ada di lembaga pemasyarakatan. Tentunya harus dielaborasikan dengan support system yang memadai. Sistem pemasyarakatan yang ada di Indonesia ini juga sejalan dengan filosofi pemasyarakatan sebagai bentuk hukuman yang menjalankan prinsip pembinaan, pembimbingan dan pengayoman dengan karakter korektif, edukatif dan rehabilitatif.

\section{Kesimpulan}

Dari uraian di atas, bisa dilihat bahwa dalam hukum pidana Islam, tidak ada batas tertinggi dan terendah yang pasti dan dijadikan pedoman untuk hukuman penjara sebagai ta'zir , dan hal itu diserahkan kepada ijtihad hakim. Hazairin berpikiran bahwa pidana penjara pendek tidak dapat memerankan fungsinya sebagai alat untuk mempersiapkan terpidana melakukan resosialisasi serta pembinaan, yang justru merupakan tujuan utama pidana penjara. Konstribusi pemikiran Hazairin tersebut dalam hukum pidana Islam adalah dengan adanya dua teori yaitu teori mutlak (identik dengan jarimah hudūd (hukuman pasti) dan teori relatif (identik dengan jarimah ta'zīr), standar keadilan dalam penerapan hukuman mutlak adalah dengan menyesuaikan kehendak masyarakat dan sekaligus mempertimbangkan bentuk, kualitas dan kuantitas kejahatan yang dilakukan. Sedangkan dalam penerapan hukuman relatif adalah masyarakat secara keseluruhan dengan memperhatikan kepentingan-kepentingan individu. Dalam masa Rasulullah pernah dipraktekkan suatu jenis ta'zīr yang esensinya sangat mirip dengan pidana penjara, yaitu ta'zir berupa pembuangan. Itu berarti bahwa esensi dari ta'zir tidak berbeda 
dengan esensi pidana penjara. Namun analisis Hazairin tersebut dengan memulihkanya kembali hukum pidana Islam tidak bisa diaplikasikan dalam sebuah hukuman yang ada di Indonesia.

Dalam hal relevansi penghapusan pidana penjara pendek dalam sistem pemidanaan hukum pidana di Indonesia, berdasarkan kondisi yang ada, keberadaan pidana penjara pendek tidak dapat dihindarkan, karena dalam kenyataanya hukuman yang sering digunakan atau diputuskan oleh hakim untuk pelaku tindak kejahatan adalah hukuman penjara sekalipun waktunya pendek, sehingga pemikiran dari Hazairin tersebut belum bisa difungsikan atau diaplikasikan di dalam pemidanaan di Indonesia. Kemudian terhadap pidana alternatif pengganti pidana penjara pendek, Hazairin juga memberikan pemikiran yang solutif atas pendapatnya yaitu dengan sanksi sosial seperti mempekerjakan narapidana untuk kepentingan umum tanpa dibayar, namun hal ini belum banyak diperbincangkan.[a]

\section{DAFTAR PUSTAKA}

Amin, S.M., Pembaharuan Hukum Islam di Indonesia, Mengenang Prof. DR. Hazairin, Jakarta: Universitas Indonesia, UI Press, 1976.

Arief, Barda Nawawi, Kapita Selekta Hukum Pidana, Bandung: Citra Aditya Bakti, 2003

Kebijakan Legislatif dalam Penanggulangan Kejahatan dengan Pidana Penjara, Semarang: Badan Penerbit UNDIP, 1996.

Bunga Rampai Kebijakan Hukum Pidana (Perkembangan Penyusunan Konsep KUHP Baru), cet. ke-4, Jakarta: Kencana, 2014.

Bakry, Hasbullah, Pembaharuan Hukum Islam di Indonesia, Segi-segi yang Menarik dari Kepribadian Prof. DR. Hazairin, Jakarta: Universitas Indonesia, UI Press, 1976.

Dahlan, Abdul Azis, Ensiklopedi Nasional Indonesia, Jilid 3, Jakarta: Cipta Adi Pustaka, 1989.

Fanani, Muhyar, Membumikan Hukum Langit, Nasionalisasi Hukum Islam dan Islamisasi Hukum Nasional Pasca Reformasi, Yogyakarta: Tiara Wacana, 2008. 
Ninik Zakiyah

Hamzah, A., dan Siti Rahayu, Suatu Tinjauan Ringkas Sistem Pemidanaan di Indonesia, cet. 1, Jakarta: Akademika Pressindo1983.

Hamzah, Andi, Sistem Pidana dan Pemidanaan Indonesia (Dari Retribusi ke Reformasi), cet. 1, Jakarta: PradnyaParamita, 1986.

Hazairin, Tujuh Serangkai tentang Hukum, Bandung: Bina Aksara, 1981.

Kartono, Kartini, Patologi Sosial (Jilid 1, Edisi Baru), Jakarta: Rajawali, 1981.

Lopa, Baharuddin, al-Qur'an dan Hak-Hak Asasi Manusia, Yogyakarta: Dana Bhakti Prima Yasa, 1996.

Mannheim, Karl, Ideology and Utopia, an Introduction to the Sociology of Knowledge, terj. F. Budi Hardiman, Ideologi dan Utopia; Menyingkap Kaitan Pikiran dan Politik, Yogyakarta: Kanisius, 1991.

Mudofir, Ali, Kamus Filsuf Barat, Pustaka Pelajar: Yogyakarta, 2001.

Munajat, Makhrus, Hukum Pidana Islam di Indonesia, Yogyakarta: Bidang Akademik UIN Sunan Kalijaga, 2008.

Muslich, Ahmad Wardi, Hukum Pidana Islam, cet. 2, Jakarta: Sinar Grafika, 2005.

Priyatna, Dwidja, Sistem Pelaksanaan Pidana Penjara di Indonesia, cet. 1 Bandung: Refika Aditama, 2006.

Rahardjo, Satjipto, Pembaharuan Hukum Islam di Indonesia, Hukum Adat dalam Studi Hukum dan Masyarakat, Jakarta: Universitas Indonesia, UI Press, 1976.

Rancangan Undang-Undang tentang Kitab Undang-Undang Hukum Pidana (KUHP) Tahun 2005.

Sarup, Madam, An Introductory Guide to Post-Structuralism and Post modernism, terj. Medhy Aginta Hidayat, Post strukturalisme dan Post modernisme, Sebuah Pengantar Kritis, Jendela: Yogyakarta, 2003.

Sudarto, Kapita Selekta Hukum Pidana, Bandung: Alumni, 1981.

Tim Ensiklopedi, editor bahasa: Nina M. Armado, Ensiklopedi Islam, Jakarta: Ichtiar van Hoeve, 2005.

Tim Penulis IAIN Syarif Hidayatullah, Ensiklopedi Islam Indonesia, cet. 2, Jakarta: Djambatan, 2002.

Tongat, Pidana Kerja Sosial dalam Pembaharuan Hukum Pidana Indonesia, Jakarta: Djambatan, 2001. 